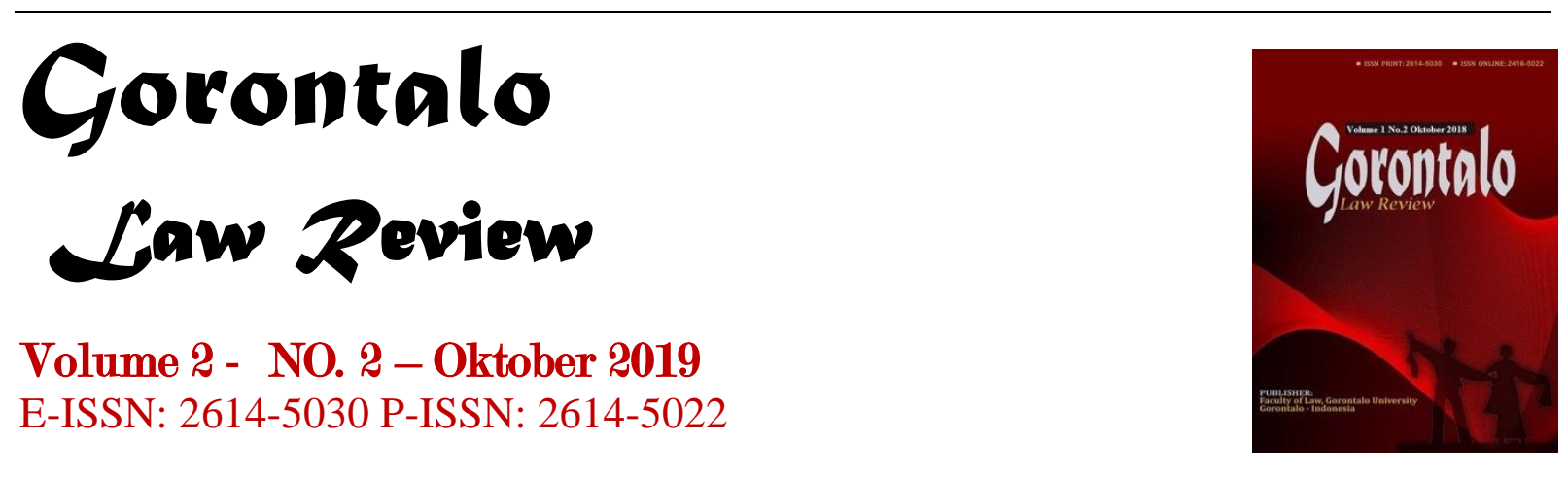

\title{
KLAUSULA PEMBATALAN SEPIHAK DALAM PERJANJIAN MENURUT PERATURAN PERUNDANG-UNDANGAN INDONESIA
}

\author{
Pahlefi \\ Fakultas Hukum Universitas Jambi \\ pahlefi@unja.ac.id \\ Raffles \\ Fakultas Hukum Universitas Jambi \\ peles_2009@yahoo.co.id \\ Herlina Manik \\ Fakultas Hukum Universitas Jambi \\ herlina_manik@unja.ac.id
}

\begin{abstract}
Abstrak
Salah satu prinsip hukum perjanjian di Indonesia, yang diatur dalam Pasal 1266 dan 1267 KUH Perdata, adalah larangan pembatalan sepihak atas perjanjian timbal balik, di mana setiap pembatalan isi perjanjian harus dilakukan di hadapan hakim. Di sisi lain, KUHPerdata juga mengakui keberadaan prinsip kebebasan berkontrak dalam suatu perjanjian. Keberadaan dua prinsip hukum di tingkat implementasi perjanjian menerima interpretasi yang berbeda dari masing-masing pihak, yang menciptakan kecenderungan untuk terjadi tuntutan hukum kepada mereka yang merasa dirugikan. Keberadaan dua putusan Mahkamah Agung yang memberikan interpretasi berbeda tentang prinsip kebebasan kontrak menunjukkan ambiguitas pemahaman prinsip kebebasan kontrak dalam relevansinya dengan larangan pembatalan sepihak. Penelitian ini bertujuan untuk menjawab masalah hukum terhadap interpretasi standar prinsip kebebasan kontrak sehingga prinsip pelarangan pembatalan masih berlaku. Sebagai studi doktrinal atau normatif, penelitian ini menggunakan pendekatan statuta, konseptual, dan kasus berdasarkan keputusan pengadilan yang memiliki "incrach" (memiliki kekuatan hukum tetap), dan analisis dilakukan secara deskriptif untuk membentuk jawaban dalam bentuk kualitatif. Hasil penelitian telah menunjukkan bahwa pembatalan unilateral Pasal 1266 dan 1267 KUHPerdata telah jelas dan eksplisit dan tidak memerlukan interpretasi. Dengan demikian, yang dibutuhkan adalah pemahaman yang jelas dan jelas tentang konsep prinsip kebebasan kontrak dalam bentuk norma hukum, sehingga diharapkan dapat memberikan kepastian hukum kepada pihak-pihak yang terikat perjanjian.
\end{abstract}




\title{
Kata Kunci: Pembatalan Sepihak; Prinsip Kebebasan Kontrak; Interpretasi Hukum; Kepastian hukum.
}

\begin{abstract}
One of the principles of treaty law in Indonesia, which is regulated in articles 1266 and 1267 of Civil Code, is the prohibition on unilateral cancellation of agreements that are reciprocal, where any cancellation of the contents of the agreement must be carried out before a judge (in court). But on the other hand, the Civil Code also recognizes the existence of the principle of freedom in contracting with an agreement. The existence of the two legal principles above at the level of the implementation of the agreement receives a different interpretation from each contractor, which creates a tendency for lawsuits to occur to those who feel disadvantaged. The existence of two Supreme Court decisions that provide different interpretations of the principle of freedom of contract shows the ambiguity of understanding of the principle of freedom of contract in its relevance to the unilateral cancellation ban. This study aims to answer legal issues against standard interpretation of the principle of freedom of contract so that the principle of prohibiting cancellations is still valid. The results of the study had shown that the unilateral cancellation of articles 1266 and 1267 of the Civil Code has been clear and explicit and does not require any interpretation. Thus, what is needed is a clear and obviously understanding of the concept of the principle of freedom of contract in the form of legal norms, so that it is expected to provide legal certainty to the parties bound to an agreement.
\end{abstract}

\section{Keywords: Unilateral Cancellation; The Principle Of Freedom Of Contract; Legal Interpretation; Legal Certainty.}

\section{PENDAhUluan}

Menurut hukum Indonesia, pembatalan perjanjian merupakan suatu konsekuensi apabila salah satu pihak ingkar janji (wanprestasi). Pengaturan tentang pembatalan perjanjian telah di atur dalam Pasal 1266 dan Pasal 1267 Kitab UndangUndang Hukum Perdata (KUHPerdata), yang intinya mengatur bahwa pembatalan perjanjian harus dimintakan kepada hakim, meskipun syarat batal tercantum atau tidak di dalam perjanjian, dan pihak yang merasa dirugikan dapat menuntut dengan pilihan memaksa pihak lain untuk memenuhi perjanjian atau menuntut pembatalan perjanjian dengan penggantian biaya, kerugian dan bunga.

Pelaksanaan perjanjian dalam kenyataannya lebih cenderung tidak sesuai dengan apa yang tertulis dalam aturan kedua pasal tersebut di atas. Hal ini sering di dapati dalam pelaksanaan perjanjian baku (standard contract). Menurut Sutan Remy Sjahdeini, perjanjian baku (standard contract) merupakan perjanjian yang sebelumnya oleh pihak tertentu (pelaku usaha) telah menentukan secara sepihak muatan isinya dengan maksud untuk dipergunakan secara berulang-ulang dalam hubungannya dengan pihak lain (konsumen) (Sutan Remy Sjahdeini, 1993). Praktek perjanjian dalam perjanjian baku (standard contract) cenderung melemahkan posisi pihak lain. Pembuat perjanjian baku dapat leluasa merumuskan klausul yang memihak kepentingan pembuat perjanjian baku, dan hal ini dapat merugikan kepentingan pihak lawan, misalnya adalah klausul pembebasan diri dari tanggung jawab atas peristiwa selama perjanjian, perumusan syarat-syarat yang membebaskan diri dari tuntutan hukum pihak lawan, dan perumusan syarat-syarat yang memberikan hak pembuat perjanjian untuk membatalkan perjanjian sewaktu-waktu tanpa persetujuan pihak lawan atau tanpa memperhatikan ketentuan-ketentuan 
dalam pembatalan perjanjian (Pasal 1266 dan Pasal 1267 KUHperdata). Klausula baku yang pada awalnya lahir demi menunjang efisiensi dan efektivitas dalam transaksi ini, pada perkembangannya dianggap berpotensi atau telah berbenturan dengan keseimbangan para pihak dalam perjanjian (Miko Susanto Ginting, 2014).

Praktek perjanjian yang mencantumkan klausul pengesampingan Pasal 1266 dan Pasal 1267 KUHPerdata semakin banyak diterapkan dalam setiap perjanjian. Atas pengesampingan pasal tersebut, apabila para pihak tidak ada yang keberatan saat syarat batal terpenuhi menjadi tidak masalah, akan tetapi apabila terdapat pihak yang keberatan, inilah yang akan menjadi masalah, karena dalam penyelesaiannya akan melibatkan pihak ketiga melalui hakim yang dapat menengahi para pihak untuk mencari keadilan.

Terdapat dua putusan Mahkamah terkait Pasal 1266 dan Pasal 1277 KUHPerdata, yaitu Putusan Mahkamah Agung No. 1527K/Pdt/2007 dan No. 2821K/Pdt/2009. Pertimbangan Mahkamah Agun dalam putusan No. $1527 \mathrm{~K} / \mathrm{Pdt} / 2007$, menyatakan bahwa pengesampingan ketentuan Pasal 1266 KUHPerdata apabila telah disepakati oleh kedua belah pihak merupakan Undangundang bagi pembuatnya, sehingga terhadap ketentuan pembatalan perjanjian sebagaimana ditentukan dalam Pasal 1266 KUHPerdata telah tertutup, oleh karenanya dalam amar putusannya, hanya mewajibkan kepada Tergugat untuk melaksanakan kewajibannya dengan adanya tuntutan kerugian terhadap keterlambatan sisa pembayaran uang perjanjian tidak membatalkan atau memutuskan perjanjian. Berbeda dengan putusan tersebut di atas, putusan Mahkamah Agung No. 2821K/Pdt/2009 yang menyebutkan dalam pertimbangannya menyatakan suatu perjanjian yang mengesampingkan Pasal 1266 KUHPerdata adalah bertentangan dengan keadilan dan itikad baik.

Melihat kedua putusan Mahkamah Agung No. 1527K/Pdt/2007 dan No. $2821 \mathrm{~K} / \mathrm{Pdt} / 2009$ tersebut, terdapat perbedaan pendapat terhadap penerapan pengesampingan Pasal 1266 KUHPerdata. Salah satu putusannya, menyatakan bahwa pengesampingan ketentuan pasal 1266 KUHPerdata apabila telah disepakati oleh kedua belah pihak, maka perjanjian adalah merupakan Undang-Undang bagi pembuatnya sebagaimana asas pacta sunt servanda, sehingga terhadap ketentuan pembatalan perjanjian sebagaimana ditentukan dalam Pasal 1266 KUHPerdata telah tertutup, artinya tidak dapat dicampuri lagi oleh pihak ketiga. Sedangkan dalam putusan yang lainnya, menyebutkan ketentuan Pasal 1266 KUHPerdata ini bersifat imperative dan tidak dapat disimpangi oleh para pihak dalam perjanjian karena sesuai dengan rasa keadilan masyarakat dan berdasarkan ketentuan Pasal 1338 KUHPerdata pada alinea ketiga, bahwa perjanjian-perjanjian harus dilaksanakan dengan itikad baik.

Berdasar uraian di atas, dengan mempertimbangkan dua putusan Mahkamah Agung tersebut tulisan hasil penelitian ini bermaksud ingin mengkaji permasalahan hukum tentang "bagaimana menurut undang-undang atas pembatalan perjanjian sepihak dengan atau tanpa pengesampingan Pasal 1266 dan Pasal 1277 KUHPerdata?.

\section{PEMBAHASAN}

\section{a. Pembatalan Perjanjian Sepihak}

Pengakhiran kontrak sepihak karena wanprestasi tanpa putusan dari hakim tidak menjadi masalah kalau pihak lain juga menerima keputusan itu. Tetapi kalau salah satu pihak menolak dituduh wanprestasi, maka para pihak sebaiknya menyerahkan keputusan kepada hakim untuk menilai ada tidaknya wanprestasi. Jika hakim menyatakan perbuatan wanprestasi terbukti dan sah, maka ingkar janji itu dihitung sejak salah salah satu pihak mengakhiri perjanjian.

Pembatalan perjanjian bertujuan membawa kedua belah pihak kembali pada keadaan sebelum perjanjian diadakan. Jika suatu pihak telah menerima sesuatu dari 
pihak lainnya, baik uang ataupun barang, maka uang atau barang tersebut harus dikembalikan. Pembatalan sepihak atas suatu perjanjian dapat diartikan sebagai ketidaksediaan salah satu pihak untuk memenuhi prestasi yang telah disepakati kedua belah pihak dalam perjanjian. Pada saat mana pihak yang lainnya tetap bermaksud untuk memenuhi prestasi yang telah dijanjikannya dan menghendak untuk tetap memperoleh kontra prestasi dari pihak yang lainnya itu.

Seperti diketahui bahwa perjanjian yang sah, dalam arti memenuhi syarat sah menurut Undang-undang, maka berlaku sebagai Undang-undang bagi para pihak yang membuatnya, sebagaimana yang tercantum dalam Pasal 1338 (1) KUHPerdata. Syarat sah tersebut sebagaimana tercantum berdasarkan Pasal 1320 KUHPerdata, yaitu: 1. sepakat mereka yang emgikatkan dirinya; 2. kecakapan untuk membuat pejanjian; 3. suatu hal tertentu; dan 4. suatu sebab yang halal. Sedangkan pada ayat (2) menyebutkan bahwa: "persetujuan-persetujuan itu tidak dapat ditarik kembali selain dengan sepakat kedua belah pihak, atau karena alasan-alasan yang oleh Undang-undang dinyatakan cukup untuk itu".

Berdasarkan Pasal 1338 ayat (2) KUHPerdata tersebut, jelas bahwa perjanjian itu tidak dapat dibatalkan sepihak, karena jika perjanjian tersebut dibatalkan secara sepihak, berarti perjanjian tersebut tak mengikat diantara orang-orang yang membuatnya. Jika dilihat dari Pasal 1266 dan 1267 KUHPerdata, maka jelas diatur mengenai syarat batal jika salah satu pihak tidak memenuhi kewajibannya. Pembatalan tersebut harus dimintakan ke pengadilan, hal ini dimaksudkan agar nantinya tidak ada para pihak yang dapat membatalkan perjanjian sepihak dengan alasan salah satu pihak lainnya tersebut tidak melaksanakan kewajibannya (wanprestasi). (Gerry R. Weydekamp, 2013)

Menurut Pasal 1266 KUHPerdata, ada tiga hal yang harus diperhatikan sebagai syarat supaya pembatalan itu dapat dilakukan. Tiga syarat itu adalah:

1) perjanjian bersifat timbal balik

2) harus ada wanprestasi

3) harus dengan putusan hakim

Perjanjian timbal balik, seperti yang telah dijelaskan di atas dimana kedua pihak memenuhi kewajibannya masing-masing, yakni prestasi. Jika salah satu pihak ingkar janji atau wanprestasi mengenai syarat pokoknya dari perjanjian, maka dapat diajukan gugatan permintaan pembatalan perjanjian kepada hakim (Abdul Kadir Muhammad, 1992).

Ada beberapa teori hukum yang terkait dengan pembatalan perjanjian ecara sepihak, yaitu repudiasi terhadap perjanjian. Repudiasi (repudiation, anticipatory) adalah pernyataan mengenai ketidaksediaan atau ketidak mampuan untuk melaksanakan perjanjian yang sebelumnya telah disetujui, pernyataan mana disampaikan sebelum tiba waktu melaksanakan perjanjian tersebut. Repudiasi dalam pengertian itu disebut repudiasi anticepatory yang berbeda dengan repudiasi biasa (ordinary) yaitu pembatalan yang dinyatakan ketika telah masuk masa pelaksanaan perjanjian (Munir Fuady, 2001).

Konsekuensi yuridis dari adanya repudiasi atas suatu kontrak adalah dapat menunda atau bahkan membebaskan pihak lain dari kewajiban melaksanakan prestasi dari perjanjian tersebut; dan di sisi lain memberikan hak kepada pihak yang dirugikan untuk dapat segera menuntut ganti rugi, sungguhpun kepada pihak yang melakukan repudiasi belum jatuh tempo untuk melaksanakan kewajibannya berdasarkan perjanjian (Munir Fuady, 2001).

Suatu tindakan repudiasi atas suatu perjanjian dapat diwujudkan dengan cara yaitu:

1) Repudiasi secara tegas

Maksudnya pihak yang menyatakan repudiasi menyatakan kehendaknya dengan tegas bahwa dia tidak ingin melakukan kewajibannya yang terbit dari perjanjian. 
2) Repudiasi secara inklusif

Di samping secara tegas-tegas, maka tindakan repudiasi dapat juga dilakukan tidak secara tegas, tetapi secara inklusif. Maksudnya dari fakta-fakta yang ada dapat diambil kesimpulan bahwa salah satu pihak telah tidak akan melakukan kewajibannya yang terbit berdasarkan perjanjian.

Kriteria utama terhadap adanya repudiasi inklusif adalah bahwa pihak yang melakukan repudiasi menunjukkan tindakan atau maksudnya secara logis dan jelas (reasonably clear) bahwa dia tidak akan melaksanakan kewajibannya yang terbit dari perjanjian. (Munir Fuady, 2001)

\section{b. Keberlakuan Asas Kebebasan Berkontrak}

Asas kebebasan berkontrak terkandung dalam Pasal 1338 KUHPerdata, yang menyatakan, "Semua perjanjian yang dibuat secara sah berlaku sebagai undangundang bagi mereka yang membuatnya. Suatu perjanjian tidak dapat ditarik kembali selain dengan sepakat kedua belah pihak, atau karena alasan-alasan yang oleh undang-undang dinyatakan cukup untuk itu. Suatu perjanjian harus dilaksanakan dengan itikad baik" (RH. Wiwoho, 2017).

Manurut Van Appeldoorn dalam RH. Wiwoho (RH. Wiwoho, 2017), menyebutkan bahwa kebebasan membuat kontrak merupakan satu di antara beberapa landasan hukum perdata. Asas tersebut ditelaah oleh pengadilan untuk mendukung penerapan standar kontrak modern sehingga dapat dilaksanakan sesuai dengan kondisi kekinian. Dalam hal ini esensi asas kebebasan berkontrak dipahami sebagai esensi kebebasan membuat kontrak dengan saling mempertahankan eksistensi masingmasing pihak, atau dengan kata lain asas kebebasan berkontrak hanya merupakan kemasan dari asas saling menjaga eksistensi antar subjek hukum kontrak. Meskipun demikian kebebasan tersebut tetap memiliki batasan, yaitu tidak melanggar kesusilaan sebagaimana di atur dalam Pasal 1337 KUHPerdata, yang berbunyi: "Suatu sebab adalah terlarang, jika sebab itu dilarang oleh undang-undang atau bila itu bertentangan dengan kesusilaan atau dengan ketertiban umum" (Muhammad Syaifuddin, 2012).

Praktik kontrak di Amerika Serikat, sebagai patron tradisi negara-negara yang menganut common law, menempatkan kebebasan berkontrak sebagai prinsip yang dibatasi oleh berbagai hal terkait kepatutan atau standar nilai lain (baik itu nilai hukum maupun non hukum). Dengan demikian, kebebasan berkontrak tidak boleh menabrak nilai-nilai yang ada. Chief Justice Charles Hughes pernah mengemukakan:

"Freedom of contract is a qualified, and not an absolute, right. There is no absolute freedom to contract as one chooses. Liberty implies the absence of arbitrary restraint -- not immunity from reasonable regulations" (M. Natsir, dkk, 2017).

Asas kebebasan berkontrak tidak dapat dimaknai sebagai kebebasan yang mutlak. Asas tersebut merupakan prinsip yang bermakna bahwa kebebasan bagi tiap individu untuk membuat kontrak dengan pihak lain tidak boleh memuat hal-hal yang manipulatif dan sewenang-wenang.

Asas kebebasan berkontrak dapat dipahami sebagai kebebasan dengan dasar tanggung jawab dan kesadaran penuh bahwa setiap orang memiliki hak dan kewajiban secara fair dan orang atau pihak lain harus menghargai dan menjaga hal tersebut. Maka dapat kemudian dipahami bahwa sikap berlindung dari tanggung jawab atas kerugian pihak lain dengan dalih kebebasan berkontrak merupakan sikap yang tidak dapat dibenarkan. Perbuatan yang bertentangan dengan hukum, yang dimasudkan untuk memperdaya pihak lain yang terlibat dalam kontrak untuk mengambil keuntungan tertentu, tidak dapat dibenarkan.

Asas kebebasan berkontrak juga bermakna tidak ada yang kebal terhadap hukum (not immunity from reasonable regulations). Kebebasan berkontrak adalah kebebasan yang bertanggung jawab dan selaras dengan makna dan tujuan dari pengaturan dalam perundang-undangan. Dari sini kemudian dapat ditarik suatu 
benang merah akan fundamentalnya peranan Hakim dalam menjaga dan mengharmonisasikan prinsip kebebasan berkontrak sebagai sebuah norma dengan penerapannya dalam kontrak para pihak. Nilai yang sebenarnya terkandung dari pembatasan asas kebebasan berkontrak adalah perimbangan hak dan kewajiban para pihak dalam suatu kontrak. Dapat dibayangkan jika para pihak diberi kebebasan tanpa batas menentukan titel hak dan kewajiban pada dirinya dan pihak lain, yang terjadi kemudian adalah ketimpangan di sana sini dan memunculkan konflik. Kontrak bukan lagi menjadi sarana untuk memenuhi kebutuhan dan meningkatkan taraf hidup, tetapi berubah menjadi sarana menguasai pihak lain. Tepatlah yang dikatakan oleh David P. Weber:

"freedom of contract is subject to some limitation; however, the general right of an individual to contractually obligate himself and receive corresponding obligations in return is so pervasive and necessary for our society as to make it a fundamental right, and as such, to be entitled to a significantly higher level of protection" (David P. Weber, 2013).

Dua putusan Mahkamah Agung Republik Indonesia tersebut di atas (Putusan Mahkamah Agung Republik Indonesia No. 1527K/Pdt/2007 dan No. $2821 \mathrm{~K} / \mathrm{Pdt} / 2009)$, nyatalah bahwa terdapat perbedaan persepsi. Dalam putusan pertama, boleh jadi para pihak telah menyepakati suatu perjanjian namun tidak dapat dipungkiri peluang adanya klausul yang tidak patut dalam perjanjian tersebut.

Walaupun adanya asas kebebasan berkontrak merupakan asas yang penting dalam perjanjian, akan tetapi dalam penerapan perjanjian, pernyataan kehendak para pihak wajib memperhatikan beberapa hal; Pertama, kebebasan berkontrak bersinggungan langsung dengan aspek keadilan; Kedua, kebebasan berkontrak dibatasi oleh norma-norma umum, seperti kepatutan, kesusilaan, dan norma umum lainnya; dan Ketiga, kebebasan berkontrak juga dibatasi oleh prinsip kepatutan dalam membebankan kewajiban kepada pihak lain.

Menurut Bismar, hakim wajib menafsirkan undang-undang agar undangundang berfungsi sebagai hukum yang hidup (living law), karena hakim tidak semata-mata menegakkan aturan formal, tetapi harus menemukan keadilan yang hidup di tengahtengah masyarakat. Lebih lanjut, Bismar menyatakan bahwa keadilan jauh lebih penting daripada kepastian undang-undang, demikian sehingga tugas utama Hakim adalah menemukan makna atau esensi dari suatu aturan atau norma hukum, alihalih prosedur hukum belaka" (Faisal, 2010).

Menurut Gustav Radbruch adalah putusan yang memuat idee des recht, yang meliputi 3 unsur yaitu keadilan (gerechtigkeit), kepastian hukum (rechtsicherheit) dan kemanfaatan (zwechtmassigkeit). Thomas Aquinas menyatakan bahwa esensi hukum adalah keadilan, oleh karena itu hukum harus mengandung keadilan. Hukum yang tidak adil bukanlah hukum itu sendiri. Dalam hal terjadi konflik antara keadilan dan kepastian hukum serta kemanfaatan, Sudikno merekomendasikan agar hakim mendahulukan keadilan (Sudikno Mertokusumo, 2011).

\section{c. Prinsip Pembatalan Perjanjian Sepihak Kaitannya Dengan Asas Kebebasan Berkontrak}

Memperhatikan dua putusan Mahkamah Agung Republik Indonesia sebagaimana tersebut di atas, menunjukkan tidak adanya konsistensi mengenai pendapat pengadilan yang terkait dengan pembatalan sepihak dalam perjanjian yang terkait dengan Pasal 1266 dan Pasal 1267 KUHPerdata. Hal ini menurut pendapat penulis sebenarnya berawal dari penafsiran tentang asas kebebasan berkontrak yang berbeda.

Pada Putusan Mahkamah Agung Republik Indonesia No. 1527K/Pdt/2007, klausul pengesampingan Pasal 1266 dan Pasal 1267 KUHPerdata merupakan tindakan yang sah dengan dasar asas kebebasan berkontrak. Hal ini tidak bertentangan dengan prinsip-prinsip kontrak. Sedangkan dalam Putusan Mahkamah 
Agung Republik Indonesia No. 2821K/Pdt/2009, ketentuan Pasal 1266 dan Pasal 1267 KUHPerdata merupakan ketentuan yang bersifat imperative dan tidak dapat disimpangi oleh para pihak.

Terhadap Pasal 1266 dan 1267 KUHPerdata apabila dilepaskan atau disimpangi oleh para pihak dalam perjanjian memiliki implikasi apabila salah satu pihak melakukan wanprestasi tidak memerlukan putusan pengadilan untuk dapat meminta ganti kerugian ataupun dimintakan pembatalaan terhadap perjanjian tersebut, dengan kata lain perjanjian menjadi batal demi hukum, melanggar ketentuan Pasal 1266 KUHPerdata ayat (4) yang mana hakim dapat memberikan suatu jangka waktu guna kesempatan memenuhi kewajibannya. Hal tersebut menjadi bertentangan dengan asas kepatutan yang diatur dalam Pasal 1339 KUHPerdata yang menyatakan "Perjanjian-perjanjian tidak hanya mengikat untuk hal-hal yang dengan tegas dinyatakan didalamnya, tetapi juga untuk segala sesuatu yang menurut sifat persetujuan, diharuskan oleh kepatutan, kebiasaan atau undang-undang." Pelepasan Pasal 1266 dan 1267 KUHPerdata yang menempatkan wanprestasi sebagai suatu syarat batal dalam Pasal 1253 KUHPerdata bertentangan dengan kepatutan dan logika, yaitu tidak selalu adil menghukum debitor yang wanprestasi karena kelalaiannya dengan pembatalan perjanjian.

Terhadap Pasal 1266 KUH Perdata akan sampai pada kesimpulan bahwa pasal ini bersifat dwingend karena tujuan pasal ini untuk melindungi salah satu pihak dari penilaian subjektif pihak yang lain. Adalah tidak adil jika penilaian mengenai tidak dipenuhinya suatu kewajiban atau wanprestasi digantungkan pada pihak lain. Hakimlah yang melakukan penilaian itu.

Ketentuan ini berkaitan dengan perikatan bersyarat atau voorwaardelijke verbintenissen. Terdapat dua jenis perikatan bersyarat, yakni syarat menangguhkan (Pasal 1263 KUHPerdata) dan syarat batal (Pasal 1265 KUHPerdata). Jenis yang kedua inilah yang menjadi fokus perhatian terkait dengan Pasal 1266 KUHPerdata dan Pasal 1267 KUHPerdata. Pada umumnya pada jenis syarat yang kedua ini dalam yurisprudensi dan oleh para penulis di Indonesia disebut sebagai syarat batal, dikarenakan kata batal menunjuk pada situasi ketika kontrak dibentuk, sedangkan dalam kaitannya dengan perikatan bersyarat, perikatannya sudah terjadi, demikian juga pelaksanaannya. Apa yang diatur di dalam Pasal 1266 KUHPerdata dan Pasal 1267 KUHPerdata ini pada dasarnya mengenai situasi tidak dipenuhinya syarat atau kewajiban dalam tahap pelaksanaan dan bukan syarat di dalam pembuatan kontrak sebagaimana ditentukan dalam Pasal 1320 KUH Perdata. Terhadap perjanjian timbal balik manakala salah satu pihak wanprestasi, syarat memutus (atau syarat bubar) merupakan syarat yang berlaku dengan sendirinya karena hukum. Dengan demikian yang membuat perikatan itu putus atau bubar yaitu karena adanya wanprestasi dan bukan putusan hakim. Kalau pun ada putusan hakim maka putusan itu sekedar mengkonstantir. Pasal 1266 KUHPerdata dan Pasal 1267 KUHPerdata karenanya dinilai sebagai aturan yang mana tidak tepat seperti dinyatakan oleh Hoge Raad: para pihak dapat untuk mengesampingkan perlunya perantaraan hakim dalam perjanjiannya.

Pasal 1266 KUHPerdata dan Pasal 1267 KUHPerdata untuk melindungi kepentingan pihak yang merasa dirugikan karena kontrak diputus secara sepihak, juga tidak tepat. Apabila terhadap pihak yang telah memenuhi kewajiban ataupun pihak yang hendak memutus kontrak, maka pihak yang dirugikan itu haruslah mendapat perlindungan hukum. Mengenai perlindungan hukum tersebut semestinya dilihat dari segi pendekatan ekonomi, hal ini dinilai sebagai pemikiran yang tidak sejalan dengan prinsip efisiensi. Pada umumnya kriteria yang dapat digunakan untuk dapat dilakukannya pemutusan sepihak adalah bila pihak lawan tidak melaksanakan kewajiban yang fundamental atau fundamental non performance, sementara 
keputusan pengadilan itu bukanlah suatu keharusan, dalam arti dapat dilakukan jika memang dikehendaki demikian.

Penyimpangan terhadap Pasal 1266 KUHPerdata dan Pasal 1267 KUHPerdata dalam praktek kontrak komersial di Indonesia merupakan suatu hal yang lazim. Dengan demikian penyimpangan tersebut memang dinilai sebagai kebutuhan. Oleh karenanya, sekalipun dari segi gramatikanya Pasal 1266 KUHPerdata ini nampak bersifat dwingend tetapi pengesampingannya di dalam kontrak dapat dinilai sebagai syarat yang biasa diperjanjikan atau bestendig gebruikelijke bedingen oleh para pihak dan secara yuridis harus dianggap mengikat. Hal ini berarti bahwa meskipun dalam kontrak disepakat adanya klausula pembatalan, namun pembatalan tersebut tidak dengan sendirinya dilakukan secara sertamerta, melainkan pembatalan harus tetap dimintakan pada pengadilan. Oleh karenanya menurut penulis bahwa pembatalan perjanjian harus didasarkan atas kesepakatan keduabelah pihak sebagaimana tersebut dalam Pasal 1338 ayat (2) KUH Perdata. Perjanjian yang bersifat timbal balik itu dapat diakhiri dengan cara membatalkan perjanjian tersebut namun pemutusan tersebut tidak dengan sendirinya melainkan harus dengan putusan pengadilan sebagaimana Pasal 1266 KUHPerdata dan Pasal 1267 KUHPerdata. Putusan pengadilan harus dilakukan meskipun dalam klausula perjanjian tercantum syarat batal, perjanjian tidak batal dengan sendirinya melainkan haruslah mengajukan permohonan pembatalan.

\section{KESIMPULAN}

Berdasarkan hasil penelitian dan pembahasan tersebut di atas, maka penulis menyimpulkan sebagai berikut;

a. secara teoretis pembatalan perjanjian sepihak tidak dapat menafikan ketentuan Pasal 1266 dan Pasal 1267 KUHPerdata, sehingga ketentuan kedua pasal tersebut pada dasarnya bersifat imperative (dwingend recht);

b. masih terdapat perbedaan panafsiran tentang asas kebebasan berkontrak dalam putusan pengadilan.

c. asas kebebasan berkontrak dapat menimbulkan ketidakadilan, karena untuk mencapai asas kebebasan berkontrak harus didasarkan pada posisi tawar (bargaining position) para pihak yang seimbang.

\section{DAFTAR PUSTAKA}

Abdul Kadir Muhamad, (1992), Hukum Perikatan, Citra Aditya, Bandung, hlm. 103.

David P. Weber, "Restricting the Freedom of Contract: A Fundamental Prohibition" Yale Human Rights and Development Journal: Vol. 16 (2013), Iss. 1, Article 2, hlm.58.

Faisal, Menerobos Positivisme Hukum, Yogyakarta: Rangkang, 2010, hlm. 5-6.

Gerry R. Weydekamp, 2013, Pembatalan Perjanjian Sepihak Sebagai Suatu Perbuatan Melawan Hukum, Jurnal Lex Privatum, Vol.I/No.4/Oktober/2013, hlm. 151.

Miko Susanto Ginting, Nopember 2014, Menegaskan Kembali Keberadaan Klausula Baku Dalam Perjanjian, Jurnal Hukum dan Peradilan, LIPI, Volume 3 Nomor 3, hlm. 224.

Munir Fuady, (2001), Hukum Kontrak: Dari Sudut Pandang Hukum Bisnis, PT. Citra Aditya Bakti, Bandung, , hlm. 105.

Muhammad Syaifuddin, Hukum Kontrak (Memahami Kontrak dalam Perspektif Filsafat, Teori, Dogmatik, dan Praktik Hukum), Mandar Maju, Jakarta, 2012, hlm. 63.

M. Natsir, dkk, (2017), Pembatasan Asas Kebebasan Berkontrak Dan Fungsi Korektif Hakim Menilai Kedudukan Para Pihak Dalam Perjanjian, Dirjen Badan Peradilan Agama Mahkamah Agung Republik Indonesia, Jakarta.

RH. Wiwoho, (2017), Keadilan Berkontrak, Penaku, Jakarta, , hlm. 28. 
Sutan Remy Sjahdeini, (1993), Kebebasan Berkontrak dan Perlindungan Yang Seimbang Bagi Para Pihak Dalam Perjanjian Kredit di Indonesia, Institut Bankir Indonesia, Jakarta, hlm. 66-68.

Sudikno Mertokusumo, (2011), Teori Hukum, hlm. 23. 